\title{
APLIKASI INSEKTISIDA NABATI BERBAHAN TANAMAN RAWA DALAM MENGENDALIKAN HAMA SAWI DI LAHAN RAWA PASANG SURUT
}

\author{
Syaiful Asikin ${ }^{1 *}$ dan Yuli Lestari ${ }^{1}$ \\ ${ }^{1}$ Balai Penelitian Pertanian Lahan Rawa \\ *Email: Syaifulasikin1958@gmail.com
}

\begin{abstract}
Vegetables are also needed by the community as a intake of fresh and healthy food to maintain a healthy body, of the many horticultural plants, green mustard/caisin/mustard (Brassica juncea L.) is one of the horticultural crops of vegetables that use their leaves. who is still young. One of the obstacles in the cultivation of mustard is pests and diseases, as for several types of mustard vegetable pests including: small grasshopper pests, Armyworm (Spodoptera litura, plutella (Plutella xylostella), and (Crocidolomia pavonana) With the level of damage to these plants quite varied between $10-25 \%$, some even cause crop failure.From the results of this study it can be concluded that the kepayang, galam and chirinyuh plants can be used as vegetable pesticides in controlling pests of mustard plants in swamps tides, especially for chirinyuh plants, this chirinyuh plant extracts in addition to functioning as a plant-based pesticide also functions as liquid leaf fertilizer, because the mustard plants show larger and greener plants compared to other plant extracts.
\end{abstract}

Keywords: Application, Botanical Insecticide, Mustard Pest.

\section{PENDAHULUAN}

Sayuran juga dibutuhkan masyarakat sebagai asupan makanan yang segar dan sehat untuk menjaga kesehatan tubuh, dari sekian banyak tanaman hortikultura, sawi hijau/caisin/sawi (Brassica juncea L.) merupakan salah satu komoditas tanaman hortikultura dari jenis sayur-sayuran yang memanfaatkan daun-daunnya yang masih muda.

Daun sawi sebagai sayuran memiliki macammacam manfaat dan kegunaan dalam kehidupan masyarakat sehari-hari. Sawi selain dimanfaatkan sebagai bahan makanan sayuran, juga dapat dimanfaatkan untuk pengobatan (Cahyono, 2003; Annisa et al., 2017).

Asikin (2015), melaporkan bahwa ditemukan beberapa jenis hama sayuran sawi diantaranya ialah : hama belalang kecil, hama ulat grayak (Spodoptera litura, ulat tritip atau plutela (Plutela xylostella), penggerek pucuk/krop kubis (Crocidolomia pavonana) dan ulat jengkal (Plusia sp). Adapun tingkat kerusakan dari hama-hama tersebut cukup bervariasi antara 10- $25 \%$, bahkan ada yang menyebabkan gagal panen.
Dalam mengendalikan hama tersebut pada umumnya selalu bermitra dengan pestisida/ insektisida kimiawi, karena hasilnya cepat terlhat, mudah digunakan dan mudah didapatkan. Menurut pengendalian hama terpadu, penggunaan bahan kimia beracun atau noestisida/insektisida kimia merupakan alternatif terakhir apabila komponen-komponen lainnya tidak mampu lagi baru aplikasi pestisida/insektisida kimia dapat digunakan.

Adapun dampak negatif dari penggunaan pestisida/insektisida kimia dapat berpengaruh buruk bagi lingkungan seperti terbunuhnya hama bukan sasaran, terbunuhnya musuh alami, terjadinya resurgwnsi dan resistensi hama dan berdampak negatif bagi komsumen dan binatang peliharaan.

Efek residu dari penggunaan pestisida dapat mencemari tanah disertai dengan matinya beberapa mikroorganisme perombak tanah, mematikan serangga dan binatang lain yang bermanfaat, sehingga terputus mata rantai makanan bagi hewan pemakan serangga. Efek negatif yang berkepanjangan pada suatu areal pertanian, akan menurunkan produktivitas lahan. Residu yang tertinggal pada tanaman, akan meracuni manusia bila 
terkonsumsi, yang akhirnya akan menimbulkan gejala berbagai macam hama dan penyakit. Tujuan yang semula untuk meningkatkan produktivitas, justru akan menjadi bumerang bagi kehidupan manusia (Iskarlia et al., 2014).

Salah satu cara untuk menghindari/mengurangi terjadinya pengaruh buruk bagi lingkungan maka pengendalian diarahkan kepada pengendalian hama yang ramah lingkungan yaitu dengan memanfaatkan bahan tanaman sebagai pengendali hama yaitu yang disebut dengan insektisida nabati/insektisida botani.

Tanaman/tumbuhan yang berpotensi sebagai bahan insektisida nabati adalah tanaman kepayang, kirinyuh dan galam. Dari hasil uji pendahuluan insektisida nabati dari tanaman kepayang, kirinyuh dan galam dapat mematikan ulat grayak pada skala laboratorium masing-masing berkisar antara Kepayang (83,00-86,33\%), Krinyuh (83,00-87,67\% dan tanaman Galam $(82,67-85,00)$. Dari hasil penelitian tersebut ketiga jenis tanaman/tumbuhan tersebut efektif dalam mengendalikan hama ulat grayak pada skala laboratorium. Untuk lebih mantap lagi ketiga ekstrak tanaman/tumbuhan tersebut diujikan kembali di lapangan di lahan rawa pasang surut.

Menurut Yulianto et al, (2013) dan Mudjib et al. (2014) pestisida nabati dapat digunakan antara lain sebagai agen pengendalian hama, yang bersifat mematikan hama, bersifat sebagai zat menghambat perkembangan serangga hama, juga bersifat sebagai zat pemikat, zat penolak, dan zat penghambat makan. Penggunaan pestisida nabati juga salah satu cara alternatif untuk mengurangi pencemaran lingkungan.

Penelitian bertujuan untuk mendapatkan insektisida nabati dari tumbuhan rawa yang efektif dalam mengendalikan hama-hama sayuran sawi di lahan rawa pasang surut.

\section{METODOLOGI PENELITIAN}

\section{Tempat dan Waktu}

Penelitian dilaksanakan pada awal Noember 2019 sampai Februari 2020 di desa Bungai Jaya, Kecamatan Basarang (Kabupaten Kapuas, Kalimantan Tengah).

\section{Bahan dan Alat}

Perlakuan ini menggunakan bahan tanaman sebagai sumber insektisida nabati yaitu tanaman/tumbuhan Kepayang, galam dan gulma krinyuh. Alat lain yang digunakan ember plastik, gunting, pisau, gunting, tikar, pengaruk, sendok dan alat pemanas water bath dan bahan yang digunakan zat pelarut aseton $70 \%$, zat pemersatu/emulgolator towen 40 .

\section{Rancangan Penelitian}

Rancangan yang digunakan dalam penelitian adalah Rancangan Acak Kelompok dengan 3 ekstrak tumbuhan rawa di tambah dengan 3 kontrol yaitu kontrol 1. Tanpa pengendalian, kontrol 2 (Insektisida nabati) berbahan mimba dan kontrol 3 (insektisida kimia) Landasihalotrin) di ulang 6 kali (Tabel. 1).

Tabel 1. Ekstrak tanaman rawa sebagai pestisida nabati terhadap hama sayuran sawi Di desa Bungai Jaya, Kec. Basarang (Kab. Kapuas, Kalteng), pada musim tanam 2019/2020.

\begin{tabular}{|c|c|c|}
\hline No. & Perlakuan & Famili \\
\hline 1. & Kepayang (Pangium edule) & Flacourtiaceae \\
\hline 2. & Galam (Melaleuca cajuputi) & Myrtaceae \\
\hline 3. & $\begin{array}{l}\text { Kirinyuh } \quad \text { (Chromolaena } \\
\text { odorata) }\end{array}$ & Asteraceae \\
\hline 4. & $\begin{array}{l}\text { Mimba (insektisida } \\
\text { nabati/pembanding) I }\end{array}$ & $\begin{array}{l}\text { Insektisida } \\
\text { nabati }\end{array}$ \\
\hline 5. & $\begin{array}{l}\text { Deltametrin(insektisida } \\
\text { sintetik/pembanding) I I }\end{array}$ & Insekt.Kimia \\
\hline 6. & $\begin{array}{l}\text { kontrol III (tanpa } \\
\text { Pengendalian) }\end{array}$ & Air \\
\hline
\end{tabular}

Sawi ditanam dengan jarak tanam $10 \mathrm{~cm}$ x 10 $\mathrm{cm}$ pada petakan dengan luasan $10 \times 10$ meter atau masing-masing $100 \mathrm{~m}^{2}$. Adapun varietas yang digunakan adalah Tosakan. Nitrogen akan diberikan pada saat tanam dengan takaran $90 \mathrm{~kg}$ N/ha. Sedangkan dolomit akan diberikan pada saat 15 hari sebelum tanam dengan takaran 1 ton/ha.

\section{Pembuatan Pestisida Nabati}

Sebagai langkah awal dari serangkaian tahapan kegiatan tersebut adalah pembuatan Insektisida nabati yaitu dibuat dalam bentuk ekstrak padat (paste) dengan cara merendam bahan tumbuhan segar kedalam pelarut (aceton/etanol) dengan perbandingan setiap 1000 gram bahan tumbuhan dicampur 5 -10 liter pelarut. Setelah direndam selama 48 jam, kemudian disaring dan hasil saringan dievaporasi dengan vacum untuk menghasilkan residu. Hasil residu dimasukkan ke dalam cawan terbuka dan 
dipanaskan pada waterbath dengan suhu $40^{\circ} \mathrm{C}$. Untuk membentuk ekstrak padat, pemanasan harus dilakukan selama kurang lebih 48 jam.

Sebelum aplikasi, terlebih dahulu ekstrak padat dicampur dengan minyak Tween 20 atau 80 dengan perbandingan 10:1 agar daya rekatnya pada tanaman lebih kuat dan penyebarannya merata pada permukaan tanaman. Mencampur ekstrak padat dengan Tween dilakukan pada plat kaca hingga merata kemudian dimasukkan air sedikit demi sedikit ke dalam gelas dan dicampur dengan air sebanyak $1000 \mathrm{ml}$ untuk setiap 2 gram ekstrak padat. Aplikasi di lapangan dilakukan dengan cara menyemprotkannya pada setiap petak perlakuan pada saat tanaman sayuran berumur 5-7 hari setelah tanam. Pengamatan dilakukan terhadap intensitas kerusakan daun 3 hari setelah aplikasi hingga menjelang panen dengan frekuensi pengamatan setiap 1 minggu.

Penilaian intensitas kerusakan serangan hama dilakukan dengan rumus :

$$
\begin{gathered}
\Sigma(\text { ni x vi) } \\
\text { Z x N }
\end{gathered}
$$

Dimana:

P: Intensitas serangan yang menyebabkan kerusakan bervariasi

ni : Banyaknya daun dari katagori serangan ke i

vi : Nilai skala dari daun tanaman terserang yang diamati dari katagori serangan ke $\mathrm{i}$

$\mathrm{N}$ : Banyaknya daun tanaman yang diamati

Z: Nilai skala dari kategori serangan yang ditetapkan tertinggi

Tabel 2. Nilai skala katagori serangan

\begin{tabular}{cc}
\hline Kategori & Kerusakan daun \\
\hline 0 & Daun tanaman sehat \\
1 & Kerusakan daun $<25 \%$ \\
2 & Kerusakan daun $>25 \%-<50 \%$ \\
3 & Kerusakan daun $>50 \%-<75 \%$ \\
4 & Kerusakan daun $>75 \%$ \\
\hline
\end{tabular}

\section{HASIL DAN PEMBAHASAN}

\section{Intensitas Kerusakan Daun Sawi}

Penelitian lapangan dilaksanakan di desa Bungai Jaya, Kec. Basarang (Kabupaten Kapuas, Kalteng) pada MT. 2018. Jenis hama yang menyerang pertanaman sawi di desa Bungai Jaya, Kec. Basarang (Kabupaten Kapuas, Kalteng) pada MT. 2018 adalah hama belalang, ukat grayak, hama plutella dan ulat krop kubis.

Pada pengamatan pertama yaitu 10 hari setelah tanam intensitas kerusakan daun sawi berdasarkan uji statistik, tidak menunjukkan adanya perbedaan antar perlakuan ekstrak tanaman dengan perlakuan dan kontrol pestisida sintetik (Deltametrin), tetapi berbeda nyata dengan kontrol tanpa perlakuan (Tabel $3)$.

Adapun tingkat kerusakan daun tanaman sawi berkisar antara 3,0 - 10,5\%. Masih rendahnya tingkat serangan hama akibat tanaman sawi masih kecil mengakibatkan kunjungan hama daun sedikit disamping itu pula kerja dari insektisida nabati tersebut sehingga kerusakan rendah. Asikin 2015 melaporkan bahwa pada umumnya insektisida nabati dari tumbuhan rawa mempunyai kandungan zat anti makan atau antifedan sehingga hama yang datang menyerang tanaman sawi tidak mau makan karena ekstrak tumbuhan Kepayang, Kirinyuh dan Galam mengandung zat anti makan.

Larva tidak mau makan pada ekstrak galam tersebut disebabkan adanya zat antimakan yang dimiliki oleh skstrak galam tersebut. Zat anti makan yang dimiliki oleh ekstrak galam tersebut diduga bahwa ekstrak galam tersebut mengandung zat anti makan adan alelokimia tergantung pada dosisnya. Hal ini sesuai dengan Hsiao (1985) reaksi serangga terhadap senyawa alelokimia tertentu tergantung pada dosisnya. Penghambatan total oleh suatu senyawa anti makan (feeding detterent atau antifeedant) terjadi pada kisaran dosis efektif tertentu. Penurunan konsumsi makan larva uji diduga karena kandungan senyawa alelokimia yang terdapat dalam ekstrak daun tanaman (Trisnowati et al ., 2012).

Menurut Schoonhoven (1982) alkaloid dan terpenoid sangat berpotensi sebagai penghambat makan pada sejumlah serangga. Biasanya pada larva Lepidoptera ditemukan suatu reseptor khusus berupa sel sensilla yang terdapat pada maksila. Sel tersebut dapat merespon berbagai alkaloid yang pada konsentrasi tertentu beraksi sebagai penghambat makan. Menurut Mulyaman et al. (2000) mengatakan bahwa senyawa penurunan konsumsi makan larva uji pada daun sirsak diduga karena kandungan senyawa 
Tabel 3. Efikasi ekstrak tumbuhan rawa terhadap intensitas kerusakan daun sawi (\%) di desa Bungai Jaya, Kec. Basarang (Kabupaten Kapuas, Kalteng) pada MT. 2018.

\begin{tabular}{lllrrr}
\hline No. & Perlakuan & Nama Ilmiah & \multicolumn{3}{c}{ Intensitas Kerusakan Daun (\%) } \\
\cline { 3 - 5 } & & & 10 HST & 20 HST & 30 HST \\
\hline 1. & Kepayang & P.edule & $3,0 \mathrm{~b}$ & $3,0 \mathrm{~b}$ & $10,5 \mathrm{~b}$ \\
2. & Galam & M.cajuputi & $3,0 \mathrm{~b}$ & $3,0 \mathrm{~b}$ & $9,5 \mathrm{~b}$ \\
3. & Krinyuh & C.odorata & $3,0 \mathrm{~b}$ & $3,5 \mathrm{~b}$ & $10,5 \mathrm{~b}$ \\
4. & Deltametrin (insekt kimia/ pembanding) I & & $3,5 \mathrm{~b}$ & $3,5 \mathrm{~b}$ & $12,5 \mathrm{~b}$ \\
5. & Mimba (insekt nabati/pembanding) II & & $5,5 \mathrm{~b}$ & $7,5 \mathrm{~b}$ & $17,5 \mathrm{~b}$ \\
6. & Tanpa dikendalikan (pembanding) III & & $10,5 \mathrm{a}$ & $17,75 \mathrm{a}$ & $45,5 \mathrm{a}$ \\
\hline
\end{tabular}

Keterangan : Angka yang diikuti oleh huruf yang sama pada baris yang sama tidak berbeda nyata menurut uji DMRT pada taraf $5 \%$.

alelokimia yang terdapat dalam ekstrak daun sirsak. Kelompok senyawa padatanaman sirsak adalah annonain, annoniin, muricine,muricinine, reticuline, serta asam hidrosianik (Morton,1987). Menurut Schoonhoven (1982) alkaloid dan terpenoid sangat berpotensi sebagai penghambat makan pada sejumlah serangga. Bisa nya pada larva Lepidoptera ditemukan suatu reseptor khusus berupa sel sensilla yang terdapat pada maksila. Sel tersebut dapat merespon berbagai alkaloid yang pada konsentrasi tertentu beraksi sebagai penghambat makan.

Pada konsentrasi yang tinggi acetogenin akan bersifat anti makan pada serangga, sedangkan pada konsentrasi rendah bersifat sebagai racun perut dan dapat menyebabkan kematian. Beberapa peneliti mengatakan bahwa suatu senyawa yang mempunyai aktivitas sebagai anti makan terlihat berpengaruh pada konsentrasi yang dapat menghambat makan hingga 50\% (Rose et al., 1981 dalam Schoonhoven, 1982). Namun beberapa peneliti lainnya mengatakan bahwa senyawa anti makan efektif bila dapat menghambat makan sekitar 80-100\% (Schoonhoven, 1982). Dengan demikian ekstrak tumbuhan galam ini mengandung zat antimakan dan bersifat racun perut.

Meisarani dan Ramadhania 2016, Melaleuca leucadendron Linn. merupakan spesies tanaman dari suku Myrtaceae yang berasal dari Australia dan terdistribusi secara luas ke beberapa negara lain seperti Brazil, India, Cuba, serta Asia bagian selatan termasuk Indonesia. Tanaman ini memilki banyak khasiat sebagai obat alami, dimana minyak essensialnya telah dibuktikan secara empiris dan ilmiah memiliki efektivitas farmakologi melalui pengujian in vitrodan in vivo, hal ini disebabkan karena kandungan senyawa kimianya seperti 1,8-
Sineol, $\alpha$-Terpineol,serta $\beta$-Kariofilen dan $D$ Limonenyang merupakan senyawa kimia utama pada tanaman ini, memiliki efek farmakologi yang ditimbulkan, diantaranya adalah aktivitas antioksidan, antifungal, efek sedatif, serta inhibitor enzim hyaluronidase. Mutiah et al., (2013), bahwa ekstrak tumbuhan selalu bereaksi dengan lambat dibandingkan dengan insektisida kimiawi.

Pada pengamatan kedua yaitu 20 hari setelah tanam (hst), tingkat kerusakan tanaman meningkat yaitu pada perlakuan kontrol tanpa pengendalian sebesar $17,75 \%$. Sedangkan pada perlakuan ekstrak tanaman masing-masing 5,0\% (kepayang, galam dan krinyuh), dan pada perlakuan insektisida nabati mimba $7,5 \%$. Secara uji statistik semua peraluan tidak menunjukkan adanya perbedaan kecuali dengan perlakuan kontrol tanpa pengendalian. Dengan demikian perlakuan ekstrak/pestisida nabati tidak berbeda dengan kontrol pestisida kimiawi.

Pada pengamatan selanjutnya yaitu 30 hst (hari setelah tanaman), tingkat serangan tertinggi yaitu pada perlakuan kontrol tanpa pengendalian yaitu sebesar 45,5\%. Pada perlakuan ekstrak tanaman kepayang, galam dan kirinyuh masing-masing 10,5\%, $9,5 \%$ dan10,5\%. Secara uji statistik ekstrak kepayang, galam dan kirinyuh dan kontrol pestisida kimia Deltametrin tidak menunjukkan adanya perbedaan, bahkan tingkat serangan pada kontrol pestisida kimiawi lebih tinggi dibanding ekstrak tanaman kepayang, galam dan kirinyuh.

Tumbuhan kepayang (Pangium edule) selain mengandung sianida juga mengandung bahan aktif lainnya seperti Pyrethrin, bahan aktif dari senyawa Pyrethrin bekerja dengan cara mengganggu jaringan 
saraf serangga. Pyrethrin bekerja dengan cepat dan dapat langsung membuat pingsan serangga.

Pyrethrin mempunyai daya racun yang rendah pada manusia dan mamalia, pyrethrin lebih beracun bagi mamalia jika tercium (inhalasi), karena proses inhalasi menyediakan lebih banyak jalur bagi pyrethrin mencapai aliran darah yang menuju keotak. Pyrethrin merupakan racun kontak yang tidak meninggalkan residu, sehingga pestisida ini sering disebut sebagai pestisida yang aman bagi lingkungan. Pyrethrin cepat terurai oleh sinar matahari dan kelembaban udara, penguraian yang lebih cepat terjadi pada kondisi asam dan basa. Oleh sebab itu bahan yang mengandung pyrethrin tidak boleh dicampur dengan kapur (Novizan, 2002).

Menurut Campbell (1933) dan Burkill (1935) dalam Nunik et al. (1997) jenis tumbuhan yang telah diketahui berfungsi sebagai bahan obat, insektisidal dan repelen atau attraktan mengandung senyawa bioaktif seperti alkaloid, terpenoid, steroid, asetogenin, fenil propan, dan tanin.

Ekstrak tanaman galam mengandung bahan bioaktif berdasarkan hasil uji pendahuluan fitokimia terhadap daun galam menghasilkan uji positif terdapat golongan senyawa fenolik, flavonoid, dan terpenoid. Senyawa fenolik dapat menunjukkan pengaruh fisiologi pada hewan, beberapa senyawa ini bersifat menolak atau racun terhadap hewan pemangsa tumbuhan (herbivor), dan bersifat racun serangga (insektisida), sementara senyawa fenol yang lain mempengaruhi perkembangbiakan binatang pengerat. Efek flavonoid terhadap berbagai organisme sangat banyak macamnya dan dapat dipakai dalam pengobatan tradisional, kerja antimikroba dan antivirus serta berpengaruh terhadap serangga. Terpenoid memiliki peran pelindung terhadap serangga, golongan seskuiterpenoid mempunyai efek fisiologi yang nyata terhadap tumbuhan dan hewan, senyawa aktifnya yaitu senyawa yang mengandung gugus fungsi lakton menonjol. Beberapa seskuiterpenoid lakton berdaya racun, yang lain merupakan kandungan tumbuhan obat yang baik dan bekerja sebagai penolak serangga, insektisida dan fungisida (Robinson, 1995).

Minyak atsiri yang dihasilkan oleh tumbuhan galam mengandung 1,8-sineol, linalool, alfaterpineol, terpinen-4-ol, terpinil asetat, pinena, nerolidol, leavo-pinena, farnesol, fitol, squalena, allaromadendrena, ledena, palustrol, viridiflorol, ledol, betulinaldehid, asam betulinat, asam platanat, limonena, dipentena, azulen, sesquiterpen, valerianik aldehid dan benzaldehid (Arnita, 2011).

Minyak atsiri tumbuhan galam ini telah diuji memiliki aktivitas antibakteri. Ekstrak metanolnya juga diuji memiliki aktivitas antiherpes simplex virus tipe 1. Ekstrak kloroform yang mengandung senyawa triterpene dan ekstrak metanol yang mengandung senyawa aktif piceatannol dan oxyresveratol telah diuji sebagai antihistamin. Sementara itu senyawa aktif betulin dan asam betulinat telah diuji memiliki aktivitas anti tumor (Arnita, 2011).

Tumbuhan Kirinyuh (Chromolaena odorata) merupakan semak berkayu yang berkembang pesat, asli Amerika Selatan dan Amerika Tengah. Telah diperkenalkan ke daerah tropis Asia, Afrika dan Pasifik, di mana ia adalah gulma invasif. Juga dikenal sebagai gulma Siam, berdiri membentuk padat yang mencegah pembentukan jenis tanaman lainnya. Ini merupakan pesaing agresif dan mungkin memiliki efek allelopati. Ini juga merupakan gangguan gulma di lahan pertanian dan perkebunan. Prawiradiputra (2007), tanaman ini dianggap suatu gulma yang sangat merugikan karena: (1) dapat mengurangi kapasitas tampung padang penggembalaan, (2) dapat menyebabkan keracunan, bahkan mungkin sekali kematian ternak, (3) menimbulkan persaingan dengan rumput pakan, sehingga mengurangi produktivitas padang rumput, dan (4) dapat menimbulkan bahaya kebakaran.

Tanaman Kirinyuh ini cukup efektif dalam mengendalikan hama perusak tanaman sepeti ulat grayak, ulat jengkal, ulat kubis/plutella dan ulat buah (Thamrin et al., 2013).

Biller et al. (1994), melaporkan bahwa Kirinyu mengandung Pas (Pryrrolizidine Alkaloids) sebagai racun, dan kandungan ini menyebabkan tanaman ini berbau menusuk, rasa pahit, sehingga bersifat repellent dan juga mengandung allelopati.

Kirinyuh (Chromolaena odorata) adalah salah satu tumbuhan yang dapat digunakan sebagai larvasida alami. Tumbuhan ini mengandung senyawa fenol, alkaloid, triterpenoid, tanin,flavonoid (eupatorin) dan limonen. Kandungan tanin yang terdapat dalam daun kirinyuh adalah 2,56\%. Menurut Ikhimioya (2003), Chromolaena odorata mengandung zat antinutrisi. Kandungan antinutrisi Chromolaena odorata adalah sebagai berikut: 
Haemagglutinnin $9.72 \mathrm{mg} / \mathrm{g}$, Oxalate $1.89 \%$, Phytic acid $1.34 \%$ dan Saponin 0.50\%.

Tanin tersebar luas pada tumbuhan berpembuluh, dalam angoespermae terdapat khusus dalam jaringan kayu. Di dalam tumbuhan letak tanin terpisah dengan protein dan enzim sitoplasma, tetapi bila jaringan dirusak misalnya bila hewan memakannya maka reaksi penyamakan dapat terjadi. Reaksi ini protein lebih sukar dicapai oleh cairan pencernaan hewan. Sebahagian besar tumbuhan yang banyak mengandung tanin dihindari oleh hewan pemakan tumbuhan karena rasanya yang sepet. (Rustaman et al. 2007).

\section{KESIMPULAN}

Hasil penelitian ini dapat disimpulkan bahwa tanaman kepayang, galam dan kirinyuh dapat digunakan sebagai bahan insektisida nabati dalam mengendalikan hama-hama pemakan daun tanaman sawi di lahan rawa pasang surut. Khusus untuk tanaman kirinyuh, ekstrak tanaman kirinyuh ini selain berfungsi sebagai insektisida nabati juga berfungsi sebagai pupuk daun cair, karena tanaman sawi pada perlakuan ekstrak kirinyuh tersebut memperlihatkan tanamannya lebih besar dan lebih hijau dibandingkan ekstrak tanaman yang lainnya.

\section{DAFTAR PUSTAKA}

Annisa, M., Djukri, M dan IGP Suryadarma. 2017. Pengaruh Lumut (Bryophyta) Sebagai Komposisi Media Tanam Terhadap Pertumbuhan dan Produksi Tanaman Sawi Hijau (Brassica juncea L.),Jurnal Perodi Biologi Vol 6 No 2 Tahun 2017. Hal. 44-54.

Arnita, P. 2011. Pengaruh varietas dan kerapatan daun kayu putih (Linn.) dalam ketel terhadap rendemen dan mutu minyak kayu putih. Skripsi Departemen Hasil Hutan Institut Pertanian Bogor. Tidak dipublikasikan.

Asikin . S \& M. Thamrin. 2010. Tumbuhan Rawa Asal Kalimantan Selatan dan Tengah yang berpotensi Sebagai Insektisida Nabati. Dalam Sutiman,. B.S.; A.Molyono. , E. Budi.M., Cahyo.C., F. Rosi., T. Kustono. A., E. Setyawati., Novi. A., A. Aziz., M. Jamhuri., Y. Eka Putrie dan Luluk. M. Prosiding Seminar Nasional Green Technologi. Fak.Sain dan Teknologi Univ. Islam Negeri (UIN) Malang, 20 Nov. 2010.
Asikin S. 2012. Uji Efikasi Ekstrak Tumbuhan Rawa untuk Mengendalikan Hama Ulat Grayak Skala Laboratorium. Dalam Hakimah,H., Nuri Dewi,Y., Emy. R., Suprijanto,M., A. Kurnain., A. Sulaiman., Salamiah., N. Aidawati., Luthfi dan R. Wardah. Jurnal Agroscientiae 19 (3), 2012. Fakultas Pertanian. Universitas Lambung Mangkurat. Hal. 178 - 183.

Asikin. S, dan M.Thamrin. 2006. Pengendalian Hama Serangga Sayuran Ramah Lingkungan dan di Lahan Rawa Pasang Surut. Dalam Sayuran Di Lahan Rawa Teknologi Budidaya ndan Peluang Agribisnis. M. Noor., Izzuddin, $\mathrm{N}$ dan S.S. Antarlina (Eds). Balai Besar Penelitian dan Pengembangan Sumber Daya Lahan Pertanian. Balai Penelitian Pertanian Lahan Rawa (Monograf). Hal. 73 - 86.

Asikin.S. 2015. Efektivitas Ekstrak Tumbuhan Rawa Sebagai Insektisida Nabati Dalam Mengendalikan Hama Ulat Grayak. Balai Penelitian Pertanian Lahan Rawa. 9 Hal.

Baehaki, S.E, E.H. Iswanto, dan D. Munawar. 2016. Resistensi Wereng Cokelat terhadap Insektisida yang Beredar di Sentra Produksi Padi. Jurnal Penelitian Tanaman Pangan, 35(2):99-108.

Biller, A., M. Boppre, L. Witte and T. Hertman. 1994. Pyrrolizidine alkaloids in Chromolaena odorata. Phytochemistry. http//www. ens. cau.au//Chromolaena/o/o mod.html. Diakses 26 Agustus 2005

Cahyono, B. 2003. Teknik dan Strategi Budidaya Sawi Hijau. Yayasan Pustaka Nusatama:Yogyakarta.

Campbell, F.L., and W.W. Sullivan. 1933. The relative toxicity of nicotine, methyl anabasine and lupinine for culicine mosquito larvae. J.Con. Entomol. 26 (3) : 910-918.

Hasanah. N. A, Nazaruddin. F., Febrina E., dan Zuhrotun. 2011. Analisis Kandungan Minyak Atsiri dan Uji Aktivitas Antiinflamasi Ekstrak Rimpang Kencur (Kaempferia galanga L.). Jurnal Matematika \& Sains, 16 (3): 147-152.

Hsiao TH. 1985. Feeding behavior. Pp. 471-505. In:G. A. Ker $\mathrm{ku} \mathrm{t}$ a nd L . I. Gilber t, Eds.Comprehensive Insect Physiology Biochemistryand Pharmacology. Pergamon Press, Oxford. 
Ikhimiyoya. 2003. Acceptability Of Selected Common Shrubs/Tree In Nigeria By West African Dwarf Goats. Department Of Animal Science, Faculty Of Agriculture, Ambrose Alli University. Ekpoma, Nigeria.

Iskarlia GI, LRahmawati \&U Chasanah. 2014. Fungisida Nabati dari Tanaman Serai Wangi (Cymbopogon nardus) untuk MenghambatPertumbuhan Jamurpada Batang Karet (Hevea brasillensis Mueli, Arg). Jurnal Sains dan Terapan Politeknik Hasnur 3(1) Edisi 1. Hal. 1-7.

Meisarani, A dan Ramadhania Z. M. 2016. Kandungan Senyawa Kimia Dan Bioaktivitas Melaleuca Leucadendron Linn Jurnal Farmaka Suplemen , 24(2): 123- 144Nisa. K., Yuliani, dan F. Rachmadiarti . 2013. Uji Bioaktivitas Ekstrak Daun Suren (Toona sinensis) terhadap Mortalitas Larva Plutella xylostella pada Tanaman Sawi Hijau. Jurnal Lantera Bio. 2(3), 2013. Hal 203-206.

Morton FJ. 1987. Soursop (Annona muricata) In: Fruit of warm climates. http://www.hort.purdue.edu /newcrop/nexus / Annona-muricata nex.html/morton/ soursop. html. Diakses 4 Februari 2008.

Mudjib. A.M Ana Syabana \& Dewi Hastuti. 2014. Uji Efektivitas Larutan Pestisida Nabati Terhadap Hama Krop (Crocidolomia pavonana L.) pada Tanaman Kubis (Brassica oleraceae). Jurnal Ilmu Pertanian dan Perikanan, 3(1), Juni 2014. Hal. $67-72$.

Mulyaman S, Cahyaniati, Adam I, \& Mustofa T. 2000. Pengenalan pestisida nabati tanaman hortikultura. Direktorat Perlindungan Tanaman, Departemen Pertanian, Jakarta.

Mutiah, R., Listyana, A. \& Suryadinata, A., 2017. Aktivitas antikanker kombinasi ekstrak benalu belimbing (Macrosolen coachinensis) dan Bawang sabrang (Eleutherine palmifolia (L) Merr.) pada sel kanker serviks (Sel HeLa). Traditional Medicine Journal, Volume 22(3).

Novizan. 2002. Petunjuk pemupukan yang efektif. Jakarta :AgromediaPustaka.

Nunik St. Aminah,Enny.W. Lestari dan Supraptini. 1997. Penggunaan Ekstrak Buah Pucung Pangium edule Sebagai Penghambat Serangan Lalat pada Ikan Tongkol (Auxi thazar di.
Prosiding Seminar Nasional Tantangan Entomologi pada Abad XXI. Pel Cabang Bogor.

Prawiradiputra, B. R. 2007. Perubahan Komposisi Vegetasi Padang Rumput Alam Akibat Pengendalian Kirinyuh (Chomolaena odorata(L.) R.M.King and H. Robinson) di Jonggol,Jawa Barat.Tesis.Fakultas Pasca Sarjana Institut Pertanian Bogor.

Schoonhoven LM. 1982. Biologica 1 a spects of antifeedant. Ent. Exp. \& Appl. 31: 57-69.

Thamrin, S. Asikin, dan M. Willis. 2013. Tumbuhan Kirinyu Chromolaena odorata (L) (Asteraceae : Asterales) Sebagai Insektisida Nabati Untuk Mengendalikan Ulat Grayak Spodoptera litura. Jurnal Litbang Pert. 32(3), September 2013. Hal.: 112-121.

Trisnowati. B. A, E. Setyowati dan P. Sosatyo. 2012. Aktivitas Anti Makan Ekstrak daun Sirsak (Annona muricata) L.) dan Pengaruhnya Terhadap Indeks Nutrisi setruktur Membran Tperitrofik Larva instrar V Spodoptera litura F. Jurnal Hama Penyakit Tumbuhan Tropika, 12(2), September 2012. Hal. 169-176.

Yulianto N, G. Mudjiono, R. D. Puspitarini. 2013. Pengaruh Sistem Pengendalian Hama Terpadu (PHT) dan Non PHT terhadap Tingkat Populasi dan Intensitas Serangan Aphid (Homoptera: Aphididae) pada Tanaman Cabai Merah. Jurnal Hama Penyakit Tumbuhan, 1(3): 86-96. 